\title{
Role of Expert Systems in Identification and Overcoming of Dengue Fever
}

\author{
Dr. Nadeem Ahmed \\ Department of Computer Science \\ Superior University \\ Lahore, Pakistan
}

Muhammad Shoaib

Department of Computer Science

Sharif College of Engineering and Technology

Lahore, Pakistan

\author{
Adeed Ishaq \\ Department of Computer Science \& IT \\ The University of Lahore \\ Lahore, Pakistan
}

\author{
Abdul Wahab \\ Department of Computer Science \\ Superior University \\ Lahore, Pakistan
}

\begin{abstract}
This paper presents a systematic literature review on expert systems which are used for identification and overcoming of Dengue fever. Dengue is a viral disease produced by Flavivirus. The expansion of Dengue fever is because of uncontrolled population and urbanization without suitable water administration. With the quick technological enhancement, we can identify and overcome Dengue fever by using expert systems. These expert systems require knowledge of the relevant problem and techniques to infer the result in order to make decisions. The literature review provides a comparison of techniques, methodologies, limitations and advantages of different Dengue expert systems. These expert systems facilitate both doctors and patients in Dengue detection. Multiple risk factors can be eliminated by the detection of Dengue fever through expert systems at early stages of Dengue. Furthermore, we find that enhancement of knowledge base improves accuracy of expert systems.
\end{abstract}

Keywords-Expert system; rule based; Dengue; health care; disease; fever

\section{INTRODUCTION}

Dengue fever is one of the viral diseases around the world that is caused by blood feeding mosquito. Dengue fever happens due to a single stranded RNA Flavivirus, which is transmitted by mosquito bite [1], [2]. It is one of the most emerging diseases of the world [3]. There are about 20-80 million cases annually and majority of these are diagnosed as flu that causes about 24,000 deaths every year. Due to lack of proper treatment around $2.5 \%$ of the infection results to be fatal. The symptoms of this fever include joint pain, headache, muscle-pain and skin rashes [4]. Dengue ranks as the most important mosquito-borne viral disease in the world [5]. Countries which are most effected by Dengue are more than 110 in number [6]. Mainly this is due to bad sanitary conditions in underdeveloped countries. The experts provided a number of solutions regarding Dengue diagnosis but due to inexperienced doctors it is still misclassified [7]. Thus, throughout the world the experts are facing the problem of diagnosis of Dengue due to its misclassifications. The diagnosis process is quite time consuming which make things more complex. Much time is required for the identification of its correct classification. There is no problem in diagnosis if the number of patients is less but if they are huge in numbers and the country has limited resources then it becomes problematic to correctly diagnose this fever. The Dengue fever issue motivates computer experts to devise an automated and time efficient solution that correctly classify the Dengue. These automated systems for Dengue diagnosis can be deployed in faraway places as well as in epidemic situations to save precious lives.

In computer science those systems that can solve a specific problem and can reason rationally are known as Expert Systems. Expert systems require knowledge of the regarding problem and techniques to infer the result in order to make decision [39].

Today there exists a number of expert systems for disease diagnosis as for bacterial infection MYCIN, for lung disease PUFF, for angiograms ANGY, for edema PIP, for meningitis diagnosis NEOMYCIN, for chest pain MED1, for bacterial infection GUIDON and for hematological disease HEME [8][10]. There are several types of expert systems based on knowledge base, i.e. rules, cases, hybrid approach (rules and cases) and hybrid approach with ANN like Medical Expert Solution (MES) system [25]. The MES uses a knowledge base which consists of two knowledge structures, named as symptom and diseases. The MES provides medical facilities to those users who don't have access for it. Further, we will discourse research methodology, different mosquito borne diseases, related work, discussion, conclusion and future work.

\section{ReSEARCh Methodology}

\section{A. Rsearch Question}

RQ1: Does expert systems correctly identify Dengue fever?

RQ2: Does knowledge base of expert system fulfill the requirements?

RQ3: Does interfaces of expert systems are user friendly for all type of users? 


\section{B. Search Strategy}

After observing and viewing all aspects of expert systems a research has been carried out on expert systems for Dengue. The field of computer science plays a major role in this perspective because it provides us the tools and techniques for gathering data from massive data stores/sources.

1) Identification of Search Terms: From research question extract major terms and check their synonyms for search related research papers. These terms verified in relevant papers. OR operator use for concatenation of synonyms words. AND operator use for concatenation of major terms.

2) Trial search: Trial search conducted by using the following search string in Science Direct, IEEEXplore, SpringerLink and ACM digital library. Table 1 contains complete information of digital libraries with search items and search conduction date.

("Dengue" OR "Fever" OR "Malaria" OR "Rule based" OR "Artificial Neural Network") AND ("Identification" OR "Overcoming" OR "Expert system" OR "Task" OR "Factors" OR "Challenges" AND OR risks OR problems OR "issues")

TABLE I. TRAIL SEARCH RESUlTS

\begin{tabular}{|l|l|l|l|}
\hline S. No. & Digital library & Search & Conduction Date \\
\hline 1 & IEEE Explore & 144 & 01 January 2017 \\
\hline 2 & ACM Digital Library & 118 & 10 January 2017 \\
\hline 3 & Google Scholar & 101 & 15 January 2017 \\
\hline 4 & Science Direct & 12 & 20 January 2017 \\
\hline 5 & Site Seer Digital Library & 11 & 25 January 2017 \\
\hline 6 & Springer link & 8 & 29 January 2017 \\
\hline
\end{tabular}

\section{Study Selection Criteria}

Some of the papers are relevant to our research and properly defining our research scope. These papers have been included here that helped in the research and those papers which are not relevant to our research, not properly defining our research scope and their language is different, are excluded.

1) Inclusive Criteria: After viewing different papers some papers are, giving the answer of our research questions, defining our search terms, their language is English and within our scope, these papers are included.

2) Exclusion Criteria: Some papers are not within a scope or not written in the English language which is prescribed in this paper, or not giving proper answers of our research questions, such type of papers is excluded.

\section{Data Extraction and Assessment of Study Quality}

As our inclusive criteria is defined, we have gathered the data which is relevant to our research, fulfilling our requirements and defining the scope of our research, also it will guide us for quality study.

\section{E. Electronic Data Stores}

We search related data from the following electronic data sources:

- www.ieexplore.ieee.org

- www.acm.org

- www.sciencedirect.com

- www.citeseer.ist.psu.edu

- www.scholar.google.com

- www.springerlink.com

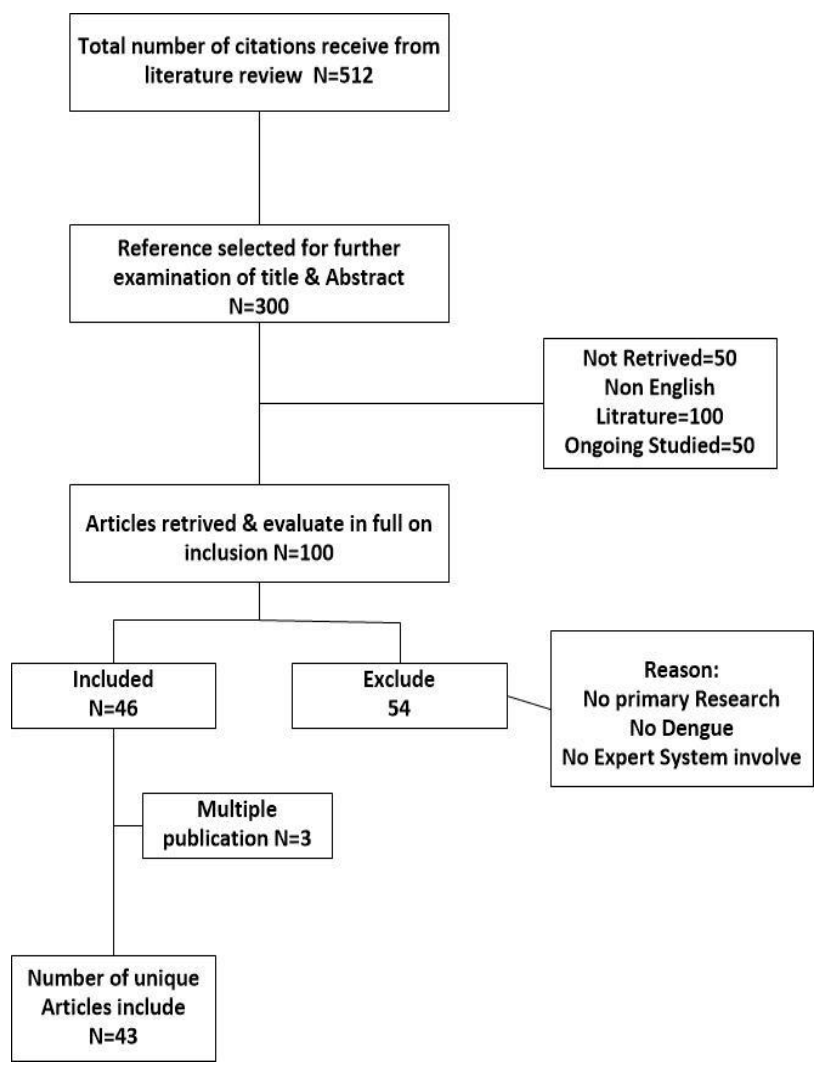

Fig. 1. Research methodology.

Fig. 1 shows complete research process and number of research paper included in our study. Duplicate publication and non-primary research studies exclude.

\section{DIFFERENT MOSQUiTo BORNE DISEASES}

Here we describe the origin of different mosquito born disease. These diseases have some common symptoms with others. Some are viral while other are non-viral. Viral diseases are either due to mosquitos like Yellow fever, Malaria, Dengue and influenza [11], whereas non-viral are natural diseases such as heart diseases, diabetes and cancer. Unlike non-viral diseases, the viral diseases can spread in short spans of time and are difficult to handle. Fig. 2 expresses hierarchical structure of viral and non-viral diseases. 


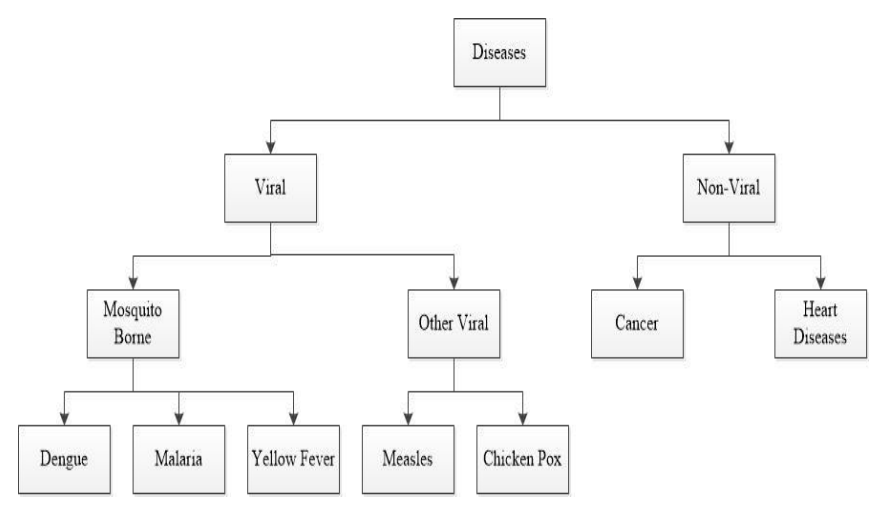

Fig. 2. Viral and non-viral diseases.

\section{A. Diseases Due to Mosquitos}

These diseases are caused by viruses that are transmitted by mosquitos. Which includes Dengue, Yellow Fever and Malaria [12]. In past years' research shows that there is leap in diseases caused by mosquitos. This motivates researchers and scientists to work to reduce these diseases [13]. Fig. 3 presents complete detail of mosquitos borne diseases.

1) Yellow Fever: It is one of the infectious diseases which is caused by Aedes mosquito that is infected by Flavivirus. This mosquito is usually found in sub-tropical or tropical regions [14].

Signs and Symptoms: Yellow Fever happens due to a virus cause by mosquito. The symptoms appear in 3 to 6 days after mosquito bite. There are three stages of this disease.

- Stage 1 (infection): The infected person shows following symptoms in first 3 to 4 days, fever, loss of appetite, headache, joint pain, vomiting and jaundice. After day 4 these symptoms become brief.

- Stage 2 (remission): In this stage, most of the symptoms are gone and people can be recovered but due to carelessness the situation can get even worst.

- Stage 3 (intoxication): In organs such as liver, heart and kidney different problems may occur [15], [16].

2) Malaria: Malaria is also a disease that happens due to virus by a female mosquito Plasmodium of genus Anopheles carry. If this disease is not treated in time it may lead to complications towards death. There are two types of malaria in general: simple and severe. Simple malaria is curable if treated within time while severe malaria may lead to death.

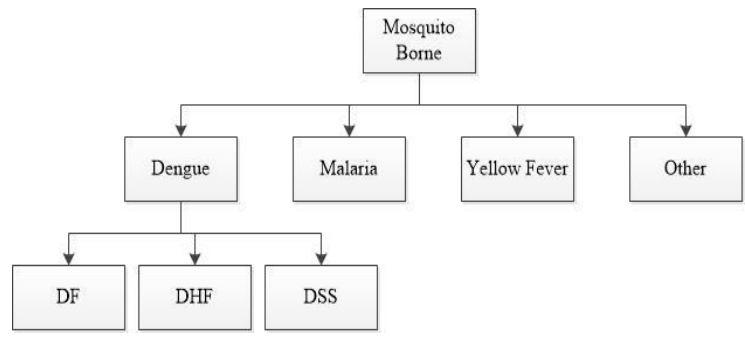

Fig. 3. Mosquitos borne diseases.

\section{Signs and Symptoms:}

- Simple Malaria: This disease remains for 6 to 10 hours. Its symptoms are, cold stage that has sense of shivering, hot stage with headache and vomiting and sweating stage. Attacking schedule is with Tertain parasite, it occurs every second day \& with Quartan parasite it occurs every third day. General symptoms are: Fever, Headache, Sweating, Vomiting, Body ache and Chills. The physical impact of malaria can be seen on the infected body that includes, getting sweaty, temperature rise up, mild jaundice, respiration increased and weakness in body.

- Severe Malaria: During simple malaria if there arise a complication of infection in any part of body by failure of any organ it may create severe malaria.

3) Dengue: Aedes aegypti is certain type of mosquitos that causes of Dengue. It is a viral disease and the virus is single-positive strand RNA virus and commonly found in subtropical and tropical regions [17].

\section{Signs and Symtoms:}

Major symptoms of Dengue are high-fever and combination of at least two which are, Pain in joints, Bleeding gums, Rashes on skin, Very low white-blood cells, Pain in bones and severe pain behind eyes. To get better a proper lookout is very necessary because after 3 to 7 days following things can happen, Red spots on body, Pale skin, Drowsiness, Pain in abdomen, Breathing in difficult. Dengue fever that stays for 2 to 7 days is normally called Dengue Hemorrhagic Fever (DHF). DHF warning appears when after 24 to 48 hours fever suddenly drops and at this time bleeding is started, due to this circulatory system is disturbed and it may lead to death [18].

World Health Organization (WHO) has worked on the Dengue risk factors that play the pivotal role in the disease diagnosis [19]. Similarly, resources have showed that Dengue is assorted disease, its symptoms are mixed with other diseases that make its detection and diagnosis more difficult [20].

\section{RELATED WORK}

\section{A. Expert System using ANN}

In this paper, SOM (Self Organization Map) was used to distinguish between healthy and Dengue infected patients. The research consists of two maps, one that contain BIA (bio impedance analysis) factors and other contains disease symptoms. The research resulted these major BIA factors; Abdominal pain, Anorexia, bleeding and rashes that were present in Dengue patients. After BIA analysis, they found 100 -unit best map size with error of 0.033 and quantization error of 1.313 [21]. Goal was to predict occurrence of Dengue by comparing weights. The learning rate varied from 0.5 to 0.9 [22]. Table 2 demonstrates advantages and disadvantages of expert systems by using artificial neural network. 
TABLE II. ADVANTAGES AND DisADVANTAGES OF EXPERT SYSTEM USING ANN

\begin{tabular}{|l|l|}
\hline Advantages & Disadvantages \\
\hline Reprogramming is not needed & Proper training is needed to operate \\
\hline $\begin{array}{l}\text { Tasks are completed by adjusting } \\
\text { weights }\end{array}$ & Large data, high processing time \\
\hline $\begin{array}{l}\text { Learning is by hit and trail } \\
\text { Easy to use and learn by examples }\end{array}$ & Lack in history maintenance \\
\hline $\begin{array}{l}\text { Perform functions that a linear } \\
\text { system can't perform }\end{array}$ & Highly dependent on data \\
\hline
\end{tabular}

\section{B. Emerge}

This is rule-based expert system which was developed to assist in emergency room. This system uses weighting factors determined by neural network. It is composed of input \& output block and a hidden layer block that communicates input to output. Neural Network learns from example \& predict an output based on this knowledge. It uses IF-THEN-UNLESS instead of IF-THEN that make more precise decision [29].

\section{Expert System using Rule based Reasoning}

Here, Dengue was detected using Rule Based Classifier that are: Decision Tree, Naïve Bayes \& Associative Classifiers. The research proved that result from more than one classifier is better than results by using one classifier. The result jumped up to $70 \%$ by using more than one classifier thus giving better result than single classifier [23]. In this paper, a Dengue diagnosis system was proposed that observe medical record procedures. It uses tree like model rather than DF and DHF. Out of the record of 41 infected 27 were classified DF, 9 were DHF-I and 5 were DHF-II [24]. Table 3 provides different advantages and disadvantages of expert systems by using rule based reason.

TABLE III. ADVANTAGES AND DisADVANTAGES OF EXPERT SySTEM USING RULE BASED REASON

\begin{tabular}{|l|l|}
\hline Advantages & Disadvantages \\
\hline $\begin{array}{l}\text { Representation of knowledge is } \\
\text { natural }\end{array}$ & Knowledge range is narrow \\
\hline Knowledge is kept separately & Cost effective expert system \\
\hline Training is used to increase skills & No creative solutions \\
\hline There is no overhead & No proper rules \\
\hline Additional help is involved & Can't learn itself \\
\hline
\end{tabular}

www.ijacsa.thesai.org

\section{D. $M Y C I N$}

MYCIN was one of the earliest diagnosis systems that used to diagnose infectious diseases caused by bacteria. First it describes the infection produced by bacteria then, it suggests antibiotic to give the infected person based on the decision [34].

\section{E. PNEUMOCONIOSIS X-RAY Diagnosis Expert System}

This expert system was developed by Miriam Kubiska and Julie Herzner in 1992. The system has inference engine to examine the shadows on the x-ray. These shadows are used to determine the degree and type of PNEUMOCONIOSIS that is a lung disease. System includes the following:

- The knowledge base that contain data of $\mathrm{x}$-ray representation.

- The interface that details the conclusions.

- Knowledge acquisition mode that allow user to add or change information.

\section{F. XDIS}

XIDS had information of more than 250-300 internal diseases and syndromes that are frequently met in practice which help experts in diagnosis. The system has instructions for each disease, if disease is curable the system will prescribe medicine but if it is unable to identify the disease it will refer to a specialist. This process takes no more than 10 minutes [29].

\section{G. Expert System using Integration of Rule base and ANN}

There is also a hybrid technique in which inference engine is updated and maintained whenever a new rule come. The purpose of new rule is to refining of time complexity and efficiency of symbolic rule. The authors explained about neural composition and how they can be shaped directly from results of experiments. Also, they explained the pattern based methodologies in comparison with Rule Based Cases [26]. The expert system was also available on mobile application. The data represented in form of decision tree \& cases were stored in table in symbolic form. They maintained database for cases and rules which show that hybrid approach make system faster and always available due to web [27].

\section{H. Role of Ultrasound in Dengue Detection}

In this paper, the authors perform a study using ultrasound rays to find that can be used to diagnose Dengue fever and also to be useful in predicting the severity of this disease. To test the study 128 people were taken as a subject that suffer Dengue disease. 40 people were identified to be positive case of Dengue, remaining underwent ultrasound again until those who were infected were differentiated from those who were not infected by Dengue virus. They found that after 5 to 7 days of ultrasound effect their gall bladder wall that got thick and had pleural effusion and ascites. They concluded that in epidemic of Dengue ultrasound can be used for diagnosis of Dengue fever [28]. Table 4 presents detail comparison of various expert systems and also express future guidelines for new researches. 
TABLE IV. COMPARISON OF DIFFERENT EXPERT SYSTEMS PROPOSED BY DIFFERENT RESEARCHERS

\begin{tabular}{|c|c|c|c|c|c|c|}
\hline Expert System & $\begin{array}{l}\text { Targeted } \\
\text { Diseases }\end{array}$ & $\begin{array}{l}\text { Expert System } \\
\text { Technique }\end{array}$ & Expert System Methodology & $\begin{array}{l}\text { Future } \\
\text { Guidelines }\end{array}$ & Advantage & Limitations \\
\hline $\begin{array}{l}\text { Medical Expert } \\
\text { Solution (MES) } \\
\text { system [29] }\end{array}$ & $\begin{array}{l}\text { Tropical } \\
\text { Diseases like } \\
\text { Dengue Fever, } \\
\text { Malaria }\end{array}$ & $\begin{array}{l}\text { 1. Inference } \\
\text { engine } \\
2 . \text { Knowledge } \\
\text { Base }\end{array}$ & $\begin{array}{l}\text { MES consist of two main } \\
\text { sections: } \\
\text { 1. User-interface: This module } \\
\text { used for Displaying } \\
\text { information and perform user } \\
\text { interaction with system } \\
\text { 2. Expert system: It consists } \\
\text { of inference engine and } \\
\text { Knowledge Base. Knowledge } \\
\text { Base consist of two elements, } \\
\text { Diseases and their symptoms. } \\
\text { MES use this data for } \\
\text { diagnosis the diseases }\end{array}$ & $\begin{array}{l}\text { 1. Enhance } \\
\text { Knowledge Base } \\
\text { for getting } \\
\text { accurate results. }\end{array}$ & $\begin{array}{l}\text { 1. Beneficial for those } \\
\text { people who don't have } \\
\text { excess to medical } \\
\text { facilities. } \\
\text { 2. Provides first aid } \\
\text { facility before going to } \\
\text { medical consultant. } \\
\text { 3. Reduce physicians } \\
\text { work. } \\
\text { 4. It can be used in } \\
\text { epidemics and war } \\
\text { environment. }\end{array}$ & $\begin{array}{l}\text { 1. Training } \\
\text { required to use } \\
\text { the system. }\end{array}$ \\
\hline $\begin{array}{l}\text { Adaptive } \\
\text { Neuro-Fuzzy } \\
\text { Inference } \\
\text { System } \\
\text { (ANFIS) [30] }\end{array}$ & $\begin{array}{l}\text { Dengue, } \\
\text { Dengue Fever, } \\
\text { Malaria }\end{array}$ & $\begin{array}{l}\text { 1. Fuzzy } \\
\text { inference system } \\
2 \text {. Hybrid } \\
\text { learning } \\
\text { algorithm for } \\
\text { ANIS }\end{array}$ & $\begin{array}{l}\text { 1. Optimization of ANIS } \\
\text { structure } \\
\text { 2. Optimization of hybrid } \\
\text { learning training parameters } \\
\text { 3. Evaluation of optimal } \\
\text { models performance }\end{array}$ & $\begin{array}{l}\text { 1. Develop such } \\
\text { kind of system } \\
\text { which can be } \\
\text { used by } \\
\text { physicians in } \\
\text { hospitals or } \\
\text { clinics. }\end{array}$ & $\begin{array}{l}\text { 1. Diagnose risk in } \\
\text { Dengue patients. } \\
\text { 2. It has better } \\
\text { performance as compare } \\
\text { to noninvasive system } \\
\text { which is developed for } \\
\text { diagnosis risks in Dengue } \\
\text { patients [32]. } \\
\text { 3. Diagnostic accuracy } \\
\text { achieved up to } 86.13 \% \text {. } \\
\text { 4. More robust and } \\
\text { reliable than Ibrahim et al. } \\
\text { [32] }\end{array}$ & $\begin{array}{l}\text { 1. Not practically } \\
\text { implemented yet. } \\
\text { 2. No module for } \\
\text { physicians. }\end{array}$ \\
\hline $\begin{array}{l}\text { Adaptive- } \\
\text { Network-Based } \\
\text { Fuzzy } \\
\text { Inference } \\
\text { System } \\
\text { (ANFIS)[31] }\end{array}$ & $\begin{array}{l}\text { Dengue, } \\
\text { Dengue Fever }\end{array}$ & $\begin{array}{l}\text { 1. Fuzzy if-then } \\
\text { rules or fuzzy } \\
\text { conditional } \\
\text { statements } \\
2 \text {. fuzzy-rule- } \\
\text { based } \\
\text { systems }\end{array}$ & $\begin{array}{l}\text { 1. Architectures and learning } \\
\text { algorithms } \\
\text { 1.1 Architecture and Basic } \\
\text { Learning Rule } \\
\text { 1.2 Batch (Off-Line) Learning } \\
\text { 1.3 Pattern (On-Line) } \\
\text { Learning } \\
\text { 2. Adaptive-network-based } \\
\text { fuzzy Inference system } \\
\text { 2.1 ANFIS architecture } \\
\text { 2.2 Hybrid learning algorithm } \\
\text { 2.3 fuzzy inference systems } \\
\text { with simplified fuzzy if-then } \\
\text { rules }\end{array}$ & & $\begin{array}{l}\text { 1. The System proposed } \\
\text { new fuzzy models for data } \\
\text { classification and feature } \\
\text { extraction. } \\
\text { 2.Fixed structure of } \\
\text { ANFIS. }\end{array}$ & $\begin{array}{l}\text { 1. Training issue } \\
\text { regarding } \\
\text { overlapping } \\
\text { between adjacent } \\
\text { membership } \\
\text { functions and } \\
\text { minimal } \\
\text { Uncertainty. }\end{array}$ \\
\hline $\begin{array}{l}\text { An Application } \\
\text { of expert } \\
\text { system }(\mathrm{AExS}) \\
{[33]}\end{array}$ & $\begin{array}{l}\text { Varicella } \\
\text { (Chickenpox), } \\
\text { Dengue Fever } \\
\text { Hands-foot- } \\
\text { and-mouth } \\
\text { disease } \\
\text { Epidemic } \\
\text { parotitis } \\
\text { (Mumps) }\end{array}$ & $\begin{array}{l}\text { 1.Forward } \\
\text { chaining } \\
\text { 2. Rule-base } \\
\text { system }\end{array}$ & $\begin{array}{l}\text { 1. User-interface } \\
\text { 2. Inference mechanism } \\
\text { 3. Explanation facility } \\
\text { 4. Knowledge acquisition } \\
\text { facility }\end{array}$ & $\begin{array}{l}\text { 1. Construct } \\
\text { AExs for large } \\
\text { computer } \\
\text { program. } \\
2 \text {. Web portal } \\
\text { design for easy } \\
\text { excess of user } \\
\text { anywhere. }\end{array}$ & $\begin{array}{l}\text { 1. It is important for } \\
\text { diagnosis of viral } \\
\text { infections. } \\
\text { 2. Provide feedback in } \\
\text { explanation component } \\
\text { and inference engine. } \\
\text { 3. Complete system with } \\
\text { experimental results. }\end{array}$ & $\begin{array}{l}\text { 1. User can only } \\
\text { select predefined } \\
\text { symptoms. } \\
\text { 2. Lack of self- } \\
\text { inference ability. }\end{array}$ \\
\hline $\begin{array}{l}\text { Web-based } \\
\text { Patient Support } \\
\text { System[35] }\end{array}$ & $\begin{array}{l}\text { Dengue, } \\
\text { Diabetes }\end{array}$ & $\begin{array}{l}\text { 1. Artificial } \\
\text { Intelligence in } \\
\text { Medicine } \\
\text { 2. Fuzzy logic } \\
\text { 3. Neural } \\
\text { Network } \\
\text { 4.Centralized } \\
\text { Databases and } \\
\text { WWW }\end{array}$ & $\begin{array}{l}\text { 1. WEB-BASED MEDICAL } \\
\text { DIAGNOSIS AND } \\
\text { PREDICTION } \\
\text { 1.1. User-interface } \\
\text { 1.2. Predication modules } \\
\text { 1.3. Diagnosis modules } \\
\text { 1.4. Database }\end{array}$ & $\begin{array}{l}\text { 1. Developed } \\
\text { distributed } \\
\text { databases for } \\
\text { improving quality } \\
\text { of treatment and } \\
\text { providing better } \\
\text { diagnosis. }\end{array}$ & $\begin{array}{l}\text { 1. Artificial intelligence } \\
\text { used to make consultancy } \\
\text { more interactive. } \\
\text { 2. Fuzzy logic used in } \\
\text { uncertainty conditions. } \\
\text { 3. ANN produce better } \\
\text { results. } \\
\text { 4. Provide Tele-health } \\
\text { care. }\end{array}$ & $\begin{array}{l}\text { 1. Not deployed } \\
\text { in working in } \\
\text { environment. } \\
\text { 2. Lack of } \\
\text { experimental } \\
\text { study. }\end{array}$ \\
\hline $\begin{array}{l}\text { Rule based } \\
\text { expert } \\
\text { system[36] }\end{array}$ & $\begin{array}{l}\text { Dengue } \\
\text { infections }\end{array}$ & $\begin{array}{l}\text { 1.Bioelectrical } \\
\text { impedance } \\
\text { analysis (BIA) }\end{array}$ & $\begin{array}{l}\text { 1. Development of a rule } \\
\text { based expert system } \\
\text { 1.1 Identifying the problem } \\
\text { 1.2 Tree Diagram } \\
\text { 1.3 Rule Based Expert System } \\
\text { 1.4 Architecture of the Expert }\end{array}$ & $\begin{array}{l}\text { 1. Applying } \\
\text { nonlinear } \\
\text { modeling } \\
\text { technique for } \\
\text { improving } \\
\text { classification }\end{array}$ & $\begin{array}{l}\text { 1. Perform Risk } \\
\text { classification in DF and } \\
\text { DHF. }\end{array}$ & $\begin{array}{l}\text { 1. Do not } \\
\text { recognize } \\
\text { complex patterns. }\end{array}$ \\
\hline
\end{tabular}




\begin{tabular}{|c|c|c|c|c|c|c|}
\hline & & & $\begin{array}{l}\text { System } \\
1.5 \text { Structure of the Patient } \\
\text { Database }\end{array}$ & $\begin{array}{l}\text { accuracy like } \\
\text { ANN. }\end{array}$ & & \\
\hline $\begin{array}{l}\text { Predicting } \\
\text { arboviral } \\
\text { disease } \\
\text { emergence } \\
\text { using Bayesian } \\
\text { networks [37] }\end{array}$ & Dengue virus & $\begin{array}{l}\text { 1. Bayesian } \\
\text { Belief Network } \\
\text { (BBN) }\end{array}$ & $\begin{array}{l}\text { 1. Framework and process of } \\
\text { BBN risk modelling and } \\
\text { Mapping } \\
\text { 2. Input data processing and } \\
\text { classification } \\
\text { 2.1 Climatic parameters } \\
\text { 2.2 Road and railroad density } \\
\text { 2.3 Seaports and airports } \\
\text { 2.4 Human population density } \\
\text { 2.5 Frequency of DENV } \\
\text { introduction } \\
\text { 2.6 Inclusion of endemicity } \\
\text { risk node } \\
\text { 3. Infection risk under current } \\
\text { summer and winter Climates } \\
\text { 4. Scenario modelling } \\
\text { 5. Sensitivity analysis of risk } \\
\text { node }\end{array}$ & $\begin{array}{l}\text { 1. Case study } \\
\text { done on a large } \\
\text { region and get } \\
\text { better results for } \\
\text { predicating } \\
\text { Dengue virus } \\
\text { risk. } \\
2 . \text { By using this } \\
\text { model other } \\
\text { diseases like } \\
\text { Chikungunya, } \\
\text { Yellow fever, and } \\
\text { Zika virus can be } \\
\text { predicted. }\end{array}$ & $\begin{array}{l}\text { 1. Identify Dengue risk in } \\
\text { different environments. } \\
\text { 2. Dengue virus risk } \\
\text { model developed which } \\
\text { predict Dengue risk in } \\
\text { particular condition. }\end{array}$ & $\begin{array}{l}\text { 1. Case study } \\
\text { perform only for } \\
\text { specific region. }\end{array}$ \\
\hline $\begin{array}{l}\text { The Integrated } \\
\text { Management of } \\
\text { Health Care } \\
\text { Strategies and } \\
\text { Differential } \\
\text { Diagnosis [38] }\end{array}$ & $\begin{array}{l}\text { Malaria, } \\
\text { Typhoid fever, } \\
\text { Cough }\end{array}$ & $\begin{array}{l}\text { 1. Combination } \\
\text { of Integrated } \\
\text { Management of } \\
\text { Child illnesses } \\
\text { (IMCI) and } \\
\text { Health } \\
\text { Information } \\
\text { Systems (HIS). }\end{array}$ & $\begin{array}{l}\text { 1. Action and disease oriented } \\
\text { differential } \\
\text { Diagnosis of malaria and } \\
\text { typhoid fever } \\
\text { 2. Knowledge engineering } \\
\text { 3. IMCI/HIS expert system } \\
\text { interface architecture } \\
\text { 4. System evaluation }\end{array}$ & $\begin{array}{l}\text { 1. Adaptive } \\
\text { interfaces can be } \\
\text { designed for } \\
\text { urban and rural } \\
\text { area users. } \\
\text { 2. Provide } \\
\text { support for } \\
\text { distributed } \\
\text { environments. }\end{array}$ & $\begin{array}{l}\text { 1. Used for diagnosis } \\
\text { Malaria and Typhoid } \\
\text { fever. } \\
\text { 2. Used in rural area } \\
\text { health care where } \\
\text { maximum people are } \\
\text { illiterate. } \\
\text { 3. Provide user-interface } \\
\text { for user interaction. } \\
\text { 4. Reduce child mortality } \\
\text { rate in rural areas. }\end{array}$ & $\begin{array}{l}\text { 1. It is stand- } \\
\text { alone application } \\
\text { which cannot be } \\
\text { run in distributed } \\
\text { environments. }\end{array}$ \\
\hline
\end{tabular}

\section{DISCUSSION AND CONCLUSION}

Dengue is a viral disease produce by Flavivirus. It has two forms: one is Dengue fever and second is Dengue hemorrhagic fever. DHF is more severe form of Dengue. It has become worldwide major problem in recent years. The expansion of Dengue fever is because of uncontrolled population and urbanization without suitable water administration. If infected female Aedes mosquitos bite human than Dengue virus transmitted in human blood. In computer science, systems that can solve a specific problem and can reason rationally are known as Expert Systems. These systems require knowledge of the relevant problem and techniques to infer the result in order to make decision. In recent years, different researchers have proposed different expert systems for identification, prescribe medicine and overcoming Dengue disease. These expert systems use different technique for getting better result like Bayesian Belief Network (BBN), Artificial Neural Networks (ANN), Fuzzy inference and Hybrid learning algorithm for ANIS.

For implementing these techniques different researchers have proposed different methodologies for determining Dengue patient's problems. The main common strategies in these methodologies are User-interface, Knowledge base engineering process and system evaluation process. Userinterface works as bridge between system and user. During designing of user interfaces careful analysis of user tasks and context must be done [40]. We suggest that user interfaces should be well formed to convey knowledge according to user mental model so that a friendly communication may be done between user and system. Mostly knowledge Base consist of two elements, Diseases and their symptoms which can be used for determining disease and predict medical suggestions related to particular disease. We find during study that knowledge base has limited expressive power. Knowledge base should update itself according to environment as if it faces a new symptom which is not added in knowledge base than it should automatically be added in the knowledge base. Knowledge base should be supported for distributed environments. System evaluation used for checking the performance of expert system. A generic mechanism required for evaluation which can be followed by every researcher during designing of expert systems. Globally define certain set of rules to evaluate the expert system.

\section{FUTURE WORK}

Furthermore, we can enhance Knowledge Base of expert systems for getting accurate results. Such kind of system should be developed which can be used by doctors and patients in web portal. Distributed databases should also be developed for improvement of quality of treatment and to provide better diagnosis. The expert system should be updated as it may be used for other diseases like Chikungunya, Yellow fever, and Zika. Adaptive interfaces should be designed for both literate and illiterate users which would help them to use these systems more easily and efficiently. Online assistance provided to semiliterate users during use of expert system can enhance their performance [42]. Ahmad, N. [41] introduced a new approach which use a virtual character for providing assistance to barely literate or deaf people. By using such kind of support, we can enhance expert system utility by offering additional services like automatic translation from text to sign language. 
Finally, autistic people are very sensitive and information technology is very useful for resolving their problem [43]. Therefore, expert system can be designed for autistic people because they also don't know how to react in this situation.

\section{REFERENCES}

[1] Gubler, D. J. (1998). Dengue and Dengue hemorrhagic fever. Clinical microbiology reviews, 11(3), 480-496.

[2] Gubler, D. J., Ooi, E. E., Vasudevan, S., \& Farrar, J. (Eds.). (2014). Dengue and Dengue hemorrhagic fever. CABI..

[3] Fajardo-Dolci, G., Meljem-Moctezuma, J., Vicente-González, E., Venegas-Páez, F. V., Mazón-González, B., \& Aguirre-Gas, H. G. (2011). [The Dengue fever in Mexico. Knowledge for improving the quality in health]. Revista Médica del Instituto Mexicano del Seguro Social, 50(6), 631-639.

[4] Sulehri, M. A., Hussain, R., \& Gill, N. I. (2012). Dengue fever its diagnosis, treatment, prevention and control. Gomal Journal of Medical Science, 6, 22-27.

[5] World Health Organization. (2012). Global strategy for Dengue prevention and control 2012-2020.

[6] Ranjit, S., \& Kissoon, N. (2011). Dengue hemorrhagic fever and shock syndromes. Pediatric Critical Care Medicine, 12(1), 90-100.

[7] Salman, A., Lina, Y., \& Simon, C. (2014). Computational Intelligence Method for Early Diagnosis Dengue Haemorrhagic Fever Using Fuzzy on Mobile Device. In EPJ Web of Conferences (Vol. 68, pp. 3-9).

[8] Ashwinkumar, U. M., \& Anandakumar, K. R. (2012, January). A WebBased Patient Support System Using Artificial Intelligence to Improve Health Monitoring and Quality of Life. In 2012 Second International Conference on Advanced Computing \& Communication Technologies (pp. 101-105). IEEE.

[9] Kumar, K. A., Singh, Y., \& Sanyal, S. (2009). Hybrid approach using case-based reasoning and rule-based reasoning for domain independent clinical decision support in ICU. Expert Systems with Applications, 36(1), 65-71.

[10] Tomar, P. P., \& Saxena, P. K. (2011). Architecture for medical diagnosis using rule-based technique. In First Int. Conf. on Interdisciplinary Research \& Development, Thailand (Vol. 25, pp. 125).

[11] National Pesticide Information Center, Diseases Transmitted by Mosquitoes,NPIC. http://npic.orst.edu/pest/mosquito/diseases.html

[12] Caraballo, H., \& King, K. (2014). Emergency department management of mosquito-borne illness: malaria, Dengue, and West Nile virus. Emergency medicine practice, 16(5), 1.

[13] World Health Organization. (2012). Global strategy for Dengue prevention and control 2012-2020.

[14] Yellow Fever: Causes, Symptoms \& Diagnosis - Healthline http://www.healthline.com/health/yellow-fever

[15] Yellow fever: Nursing2016 - Wolters Kluwer Health vol. 35, no. 7, p. 75, 2005.

[16] Ward, A. M., Gunaratne, J., \& Garcia-Blanco, M. A. (2014). Identification of Dengue RNA binding proteins using RNA chromatography and quantitative mass spectrometry. Dengue: Methods and Protocols, 253-270.

[17] Simmons, C. P., Farrar, J. J., van Vinh Chau, N., \& Wills, B. (2012). Dengue. New England Journal of Medicine, 366(15), 1423-1432.

[18] Hadinegoro, S. R. S. (2012). The revised WHO Dengue case classification: does the system need to be modified? Paediatrics and international child health, 32(sup1), 33-38.

[19] Farrar, J. J., Hien, T. T., Horstick, O., Hung, N. T., Jaenisch, T., Junghanns, T., \& Simmons, C. P. (2013). Dogma in classifying Dengue disease. The American journal of tropical medicine and hygiene, 89(2), 198-201.

[20] Faisal, T., Ibrahim, F., \& Taib, M. N. (2008, August). Analysis of significant factors for Dengue infection prognosis using the self- organizing map. In 2008 30th Annual International Conference of the IEEE Engineering in Medicine and Biology Society (pp. 5140-5143). IEEE.

[21] Husin, N. A., Mustapha, N., Sulaiman, M. N., \& Yaakob, R. (2012, September). A hybrid model using genetic algorithm and neural network for predicting Dengue outbreak. In 2012 4th Conference on Data Mining and Optimization (DMO) (pp. 23-27). IEEE.

[22] Bakar, A. A., Kefli, Z., Abdullah, S., \& Sahani, M. (2011, July). Predictive models for Dengue outbreak using multiple rulebase classifiers. In Electrical Engineering and Informatics (ICEEI), 2011 International Conference on (pp. 1-6). IEEE.

[23] Ibrahim, F., Taib, M. N., Sulaiman, S., \& Abas, W. W. (2001). Dengue fever (DF) and Dengue haemorrhagic fever (DHF) symptoms analysis from an expert system perspective. In Multi Topic Conference, 2001. IEEE INMIC 2001. Technology for the 21st Century. Proceedings. IEEE International (pp. 212-215). IEEE.

[24] Suwa, M., Scott, A. C., \& Shortliffe, E. H. (1982). An approach to verifying completeness and consistency in a rule-based expert system. Ai Magazine, 3(4), 16.

[25] Adekoya, A. F.@1,Akinwale,A. T.2 and Oke, O. E.3. A medical expert system for managing tropical diseases. Department of Computer Science, University of Agriculture, Abeokuta, Nigeria adekoyaaf@unaab.edu.ng1 www.journal.unaab.edu.ng/index.php/COLNAS/article/download/145/1 48

[26] Prentzas, J., \& Hatzilygeroudis, I. (2005). Rule-based update methods for a hybrid rule base. Data \& Knowledge Engineering, 55(2), 103-128.

[27] Sulistiarini, E. B. (2013). Representing Knowledge Base into Database for WAP and Web-based Expert System. arXiv preprint arXiv:1312.3060.

[28] Sai, P. V., Dev, B., \& Krishnan, R. (2014). Role of ultrasound in Dengue fever. The British journal of radiology.

[29] Adekoya, A. F., Akinwale, A. T., \& Oke, O. E. (2008). A medical expert system for managing tropical diseases. College of Natural Sciences Proceedings, 74-86.

[30] Faisal, T., Taib, M. N., \& Ibrahim, F. (2012). Adaptive Neuro-Fuzzy Inference System for diagnosis risk in Dengue patients. Expert Systems with Applications, 39(4), 4483-4495.

[31] Jang, J. S. (1993). ANFIS: adaptive-network-based fuzzy inference system. IEEE transactions on systems, man, and cybernetics, 23(3), 665685.

[32] Faisal, T., Ibrahim, F., \& Taib, M. N. (2010). A noninvasive intelligent approach for predicting the risk in Dengue patients. Expert Systems with Applications, 37(3), 2175-2181.

[33] Chuang, L. Y. (2016). An Application of Expert System for Diagnosing Fever Caused by Viral Infection. Journal of Life Sciences and Technologies Vol, 4(1).

[34] Shortliffe, E. (Ed.). (2012). Computer-based medical consultations: MYCIN (Vol. 2). Elsevier.

[35] Ashwinkumar, U. M., \& Anandakumar, K. R. (2012, January). A WebBased Patient Support System Using Artificial Intelligence to Improve Health Monitoring and Quality of Life. In 2012 Second International Conference on Advanced Computing \& Communication Technologies (pp. 101-105). IEEE

[36] Ibrahim, F., Mohamad, M. I., Makhtar, S. N., \& Ibrahim, J. (2007). Classification of risk in Dengue fever and Dengue haemorrhagic fever using rule based expert system. In 3rd Kuala Lumpur International Conference on Biomedical Engineering 2006 (pp. 50-53). Springer Berlin Heidelberg.

[37] Ho, S. H., Speldewinde, P., \& Cook, A. (2017). Predicting arboviral disease emergence using Bayesian networks: a case study of Dengue virus in Western Australia. Epidemiology and Infection, 145(1), 54.

[38] Adehor, A. B., \& Burrell, P. R. (2008). The integrated management of health care strategies and differential diagnosis by expert system technology: a single-dimensional approach. World Academy of Science, Engineering and Technology, 44, 533-538. 
[39] McLeod, R., \& Schell, G. P. (1998). Management information systems. Upper Saddle River, NJ: Prentice Hall

[40] Iqbal, M. W., Ahmad, N., \& Shahzad, S. K. (2017). Usability evaluation of adaptive features in smartphones. Procedia Computer Science, 112, 2185-2194.

[41] Ahmad, N. (2014). People Centered HMI's for Deaf and Functionally Illiterate Users (Doctoral dissertation, Politecnico di Torino-Universität Potsdam, Germany).
[42] Ahmad, N., Shoaib, U., \& Prinetto, P. (2015). Usability of Online Assistance From Semiliterate Users' Perspective. International Journal of Human-Computer Interaction, 31(1), 55-64.

[43] Shoaib, M., Hussain, I., Mirza, H. T., \& Tayyab, M. (2017, July). The role of information and innovative technology for rehabilitation of children with Autism: A Systematic Literature Review. In Computational Science and Its Applications (ICCSA), 2017 17th International Conference on IEEE (pp. 1-10). 